Discussion Paper No. 09-019

\title{
Noncognitive Skills, School Achievements and Educational Dropout
}

Katja Coneus, Johannes Gernandt, and Marianne Saam

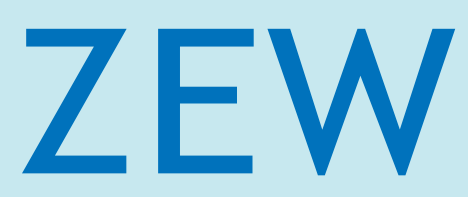

Zentrum für Europäische Wirtschaftsforschung $\mathrm{GmbH}$ Centre for European Economic Research 
Discussion Paper No. 09-019

\title{
Noncognitive Skills, School Achievements and Educational Dropout
}

\author{
Katja Coneus, Johannes Gernandt, \\ and Marianne Saam
}

Download this ZEW Discussion Paper from our ftp server:

ftp://ftp.zew.de/pub/zew-docs/dp/dp09019.pdf

Die Discussion Papers dienen einer möglichst schnellen Verbreitung von neueren Forschungsarbeiten des ZEW. Die Beiträge liegen in alleiniger Verantwortung der Autoren und stellen nicht notwendigerweise die Meinung des ZEW dar.

Discussion Papers are intended to make results of ZEW research promptly available to other economists in order to encourage discussion and suggestions for revisions. The authors are solely responsible for the contents which do not necessarily represent the opinion of the ZEW. 


\section{Non-technical summary}

Over the last three decades, public debate in most industrialized countries has seen a growing concern in the education, school-to-work-transition and social integration of low-skilled young adults. So far studies on the determinants of educational dropout have mainly focused on school achievements and family background. In addition to these factors, our paper explicitly accounts for the role of noncognitive skills, which include for example motivation, self-confidence and self-discipline.

Recent studies in the U.S. find that low noncognitive skills are an important determinant of high school dropout. Within the German system, we consider as educational dropout a person who lacks a degree from lower-secondary school or from vocational training and who is not currently in education.

Based on data from the German Socio-Economic Panel for the years 2000 to 2007 we use information on family background and last school grades as well as measures of noncognitive skills for 17-year-olds. The psychological concept of Rotter's locus of control is used to measure noncognitive skills based on the degree of agreement or disagreement with specific statements presented in the questionnaire. We consider how these magnitudes are related to the risk of being an educational dropout at the age of 17 to 21 .

The results of different econometric estimations show that even at constant family background and constant school achievements, young adults with higher noncognitive skills have a lower risk of being educational dropouts. This effect is increasing with age. One possible reason is that at the age of 17 and 18, grades play the dominant role in obtaining a school degree and successfully applying for an apprenticeship immediately after leaving school. Meanwhile noncognitive skills may have an increasing influence on ongoing failure to enter or failure to complete an apprenticeship at the age of 19 to 21 . 


\section{Das Wichtigste in Kürze}

Während der letzten drei Jahrzehnte sind die Bildung, die Eingliederung in den Arbeitsmarkt und die soziale Integration gering qualifizierter junger Menschen in den meisten industrialisierten Ländern zunehmend ins Augenmerk der öffentlichen Debatte gerückt. Bisherige Untersuchungen der Determinanten des Bildungsabbruchs schenkten vor allem den Schulleistungen und dem familiären Hintergrund Beachtung. Unsere Arbeit betrachtet neben diesen Faktoren die Bedeutung nichtkognitiver Fähigkeiten, zu denen z.B. Motivation, Selbstvertrauen und Selbstdisziplin zählen.

Neuere US-amerikanische Untersuchungen finden heraus, dass geringe nichtkognitive Fähigkeiten eine wichtige Determinante des Abbruchs der High School sind. Im Rahmen des deutschen Systems betrachten wir jene Personen als Bildungsabbrecher, die über keinen Abschluss der Sekundarstufe I oder über keinen Ausbildungsabschluss verfügen und sich auch nicht gerade in Ausbildung befinden.

Basierend auf Daten des Sozio-oekonomischen Panels für die Jahre 2000 bis 2007 nutzen wir die Angaben von 17-Jährigen über Familienhintergrund und Schulnoten sowie Maße ihrer nicht-kognitiven Fähigkeiten. Das Konzept des Rotter's Locus of Control aus der Psychologie wird verwendet, um auf Grundlage des Grades der Zustimmung oder Ablehnung bestimmter vorgegebener Aussagen ein Maß nichtkognitiver Fähigkeiten zu berechnen. Wir betrachten, in welchem Zusammenhang diese Größen mit dem Risiko stehen, Bildungsabbrecher im Alter von 17 bis $21 \mathrm{zu}$ sein.

Die Ergebnisse verschiedener ökonometrischer Schätzungen zeigen, dass auch bei gleichem Familienhintergrund und gleichen Schulnoten junge Erwachsene mit höheren nicht-kognitiven Fähigkeiten ein geringeres Risiko aufweisen, Bildungsabbrecher zu sein. Dieser Effekt steigt mit dem Alter an. Ein möglicher Grund besteht darin, dass im Alter von 17 und 18 Noten die dominierende Rolle beim Erreichen des Schulabschluss und der erfolgreichen Bewerbung um eine Lehrstelle direkt nach Verlassen der Schule spielen. Hingegen könnten im Alter von 19 bis 21 Jahren nicht-kognitive Fähigkeiten einen zunehmenden Einfluss auf den fortwährenden Misserfolg bei der Lehrstellensuche oder einen Abbruch der Lehre haben. 


\title{
Noncognitive skills, school achievements and educational dropout
}

\author{
Katja Coneus*, Johannes Gernandt ${ }^{\dagger}$ Marianne Saam
}

April 2009

\begin{abstract}
We analyse the determinants of dropout from secondary and vocational education in Germany using data from the Socio-Economic Panel from 2000 to 2007. In addition to the role of classical variables like family background and school achievements, we examine the effect of noncognitive skills. Both, better school grades and higher noncognitive skills reduce the risk to become an educational dropout. The influence of school achievements on the dropout probability tends to decrease and the influence of noncognitive skills tends to increase with age.
\end{abstract}

Keywords: noncognitive skills, school grades, secondary education, vocational training.

JEL-classification: I21; J13; J24.

Acknowledgements: We would like to thank Irene Bertschek, Andrea Mühlenweg, Friedhelm Pfeiffer, Maresa Sprietsma, Michael Ward and seminar participants at ZEW for helpful comments. Katja Coneus and Johannes Gernandt thank the Leibniz Association, Bonn, for support in the research network "Noncognitive Skills: Acquisition and Economic Consequences".

\footnotetext{
${ }^{*}$ Centre for European Economic Research (ZEW), e-mail: coneus@zew.de.

${ }^{\dagger}$ Centre for European Economic Research (ZEW), e-mail: gernandt@zew.de.

${ }^{\ddagger}$ Corresponding author: Centre for European Economic Research (ZEW), P.O. Box 1034 43, D-68034 Mannheim, Germany, tel.: +49-621-1235-285, e-mail: saam@zew.de.
} 


\section{Introduction}

Over the last three decades, public debate in most industrialized countries has seen a growing concern in the education, school-to-work-transition and social integration of low-skilled young adults. The institutional pathways and typical points of failure as well as the diagnosis in terms of dropout and unemployment rates differ across countries. But the common trend has been that a majority of countries has observed a relative deterioration of the youth labour market compared to the one for prime age workers and an increased duration of youth unemployment. Moreover, the long-term consequences of lacking general and vocational education have become more severe in terms of lower relative wages or higher unemployment risk (Ryan; 2001, Quintini et al.; 2007). Germany and other countries with a dual system combining class-based and work-based training for young adults have long been relatively successful in limiting the problem of youth unemployment. But, as our data document, a considerable share of around ten percent of young adults drops out of this system. The long-term consequences of this failed integration have sharpened. In parallel to the successful dual system, Germany's strong industrial sector traditionally offered employment and on-the-job training for school leavers without a vocational degree. Looking at the evolution of unemployment rates between 1970 and 2005, it becomes evident that the employment perspectives of those who have not completed the dual system have deteriorated markedly. Since the 1970s, the gap between the unemployment rate for the whole population and for those without vocational degree has risen from 2 to 15 percentage points. Most of the drift occurred after German reunification (see Figure 1). Reasons for educational dropout and its increasingly severe consequences can be sought on the supply and the demand side of the labour market for low- and medium-skilled workers caused e.g. by globalisation and skill biased technical change. In this paper we focus on the supply side considering individual skills, family background and previous educational achievements as determinants of educational dropout.

There are three stages at which young people can drop out of the German system of education for low- and medium-skilled workers: first, they may leave school without any degree, second, they may fail to enter an apprenticeship or a professional school after completing lower secondary education, and third, they may drop out of an apprenticeship or professional school without any degree. Using representative data from the German Socio-Economic Panel (SOEP), we analyse the determinants of educational dropout in the years following the end of compulsory schooling. Since apprenticeship combines schooling with work, our definition of educational dropout is related to both, the notion of educational dropout and the more general notion of disconnectedness (from education, work and possibly other ways of social integration) in the international literature. In both contexts, research has been paying increasing attention to the role noncognitive skills such as self-confidence and self-control play in preventing failure. In our context, noncognitive skills may lower the risk through their positive effect on school achievements as well as 
through a direct effect on aptitude and effort to successfully complete vocational education.

Figure 1: The development of the unemployment rate in Germany

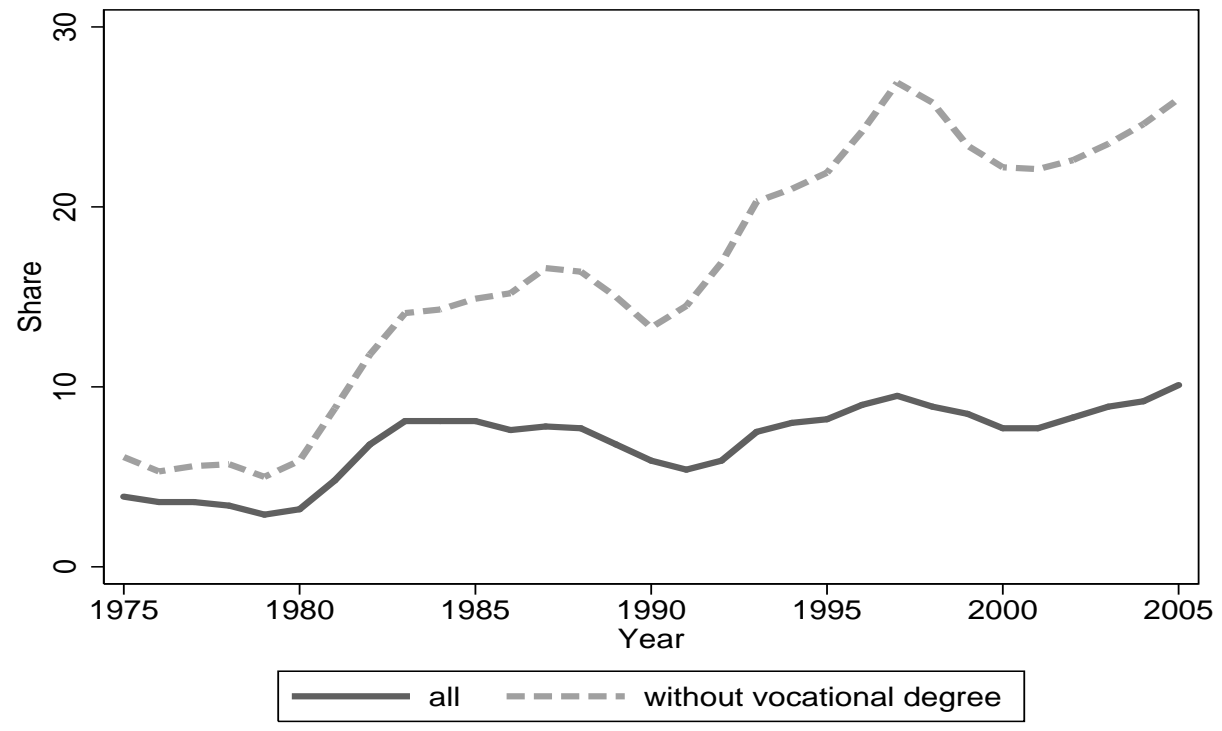

Data Source: Statistisches Bundesamt 2005.

Our analysis considers the joint effect of school achievements, which reflect academic skills, and noncognitive skills on the probability of being an educational dropout for individuals aged 17 to 21. Information on the mother's general and professional education and her professional status allows to control for the effect of family background on skills and dropout status. Moreover, the data contain information on the mother's noncognitive skills, which are also considered as determinants of the child's school achievement and noncognitive skills. Using probit models with a rich set of control variables, instrumental variables and panel models for siblings, we attempt to account for the endogeneity of skills.

While the results differ somewhat across ages and models, we find that having good grades instead of just passing grades at a given school track, which represents a difference of roughly one standard deviation, reduces the probability of being an educational dropout later on by 3 to 9 percentage points on average. A measure of noncognitive skills that is by one standard deviation higher reduces the probability of being a dropout later on by 1 to 4 percentage points. The estimation for consecutive age cohorts indicates that the influence of school achievements on the dropout probability tends to decrease and the influence of noncognitive skills tends to increase with age. 


\section{Contribution to the literature}

The present paper is situated at the intersection of the large literature on school-towork-transition and the recently emerging research on the economic importance of noncognitive skills. While there are a few studies that consider noncognitive skills in the context of educational dropout and social integration of young adults in the U.S., their role for success of young people in the German system of general and vocational education has not yet been analysed.

Our definition of educational dropout is related to earlier work by Franz et al. (2000) who look specifically at the school-to-work transition in the 1980s and the early 1990s. They highlight three stages of school-to-work transition at which failure can occur: (1) the transition from school to vocational training, (2) the completion of vocational training, (3) the transition into employment after training. Our analysis focuses on the first two stages and our definition of educational dropout will encompass all persons that experience failure at one of these stages. Failure at the first stage can result from leaving school without a degree or from not entering an apprenticeship. It is also the stage at which most failures occur, the success rates of graduating from apprenticeship lying well above 90 percent.

The educational and professional background of parents is known to be related to a variety of determinants of educational outcomes including genetic disposition, investment in education as well as preferences and other attitudes. In the German context with early ability tracking Dustmann (2004) has shown the association between the parents' education and profession, school track choices and educational and labour market outcomes of the child. In this paper we extend the analysis of parental background by examining its association with both, school grades and educational dropout. Additionally, we are able to use information on the mothers' noncognitive skills.

Our work can be placed in the more general context of the international literature on transition from youth to adulthood. In particular in the U.S., the notion of disconnectedness has been employed to refer to a situation where young people lack connection to society through school, work or family formation. In a narrow sense, being disconnected means being neither employed nor in education. In a broader sense it includes further social characteristics. MaCurdy et al. (2006) investigate spells of disconnection for young people. Beginning their first disconnecting spell more than 70 percent remain disconnected after one year, nearly 30 percent after two years and 7 percent continue their disconnection spell after three years. Our definition of dropout is limited to education and does not include employment. But as vocational education in Germany combines school and work, the definition includes those that have not begun or not completed successfully a qualifying work experience. It is related to the notion of disconnectedness but more specific. More directly focusing on labour market outcomes, there exists a U.S. literature that 
studies high school dropouts who have passed the General Educational Development credential (GED). It consists of a written test that certifies competencies in mathematics, natural and social sciences, reading and writing at the level of a high school diploma. Murnane et al. (1998) use natural experiments created by interstate variations in GED passing standards to reduce the bias from self-selection in estimating the effect of the GED on the earnings of young dropouts. Murnane et al. (2000) examine the return to cognitive skills on earnings using information on individuals who dropped out of school and later attempted to acquire a GED credential. Their result indicates substantial earning returns to cognitive skills as measured by GED test scores for all groups except white male dropouts. Heckman and Rubinstein (2001) were the first to note that noncognitive skills may play a special role in the characteristics of GED participants. GED participants seem to earn higher wages than ordinary school dropouts, which is in line with the entire literature in the importance of cognitive skills in determining labour market outcomes. However, their results indicate, when controlling for cognitive abilities, the GED participants earn the same or even less than ordinary dropouts. Heckman and Rubinstein (2001) conclude that GED participants have higher cognitive skills than other dropouts but exhibit at least as strong problems of self-control and self-discipline as other dropouts. Heckman et al. (2006) provide further evidence on this relation. They also find that both types of skills have an important effect on the decision to drop out from high school. In a similar vein, we examine in this paper whether noncognitive skills contribute to the probability of becoming an educational dropout in Germany when academic skills are held constant.

While there is to date little work focusing specifically on the role of noncognitive skills for dropouts, a growing literature has been analysing their influence on other outcomes. Borghans et al. (2008) present an overview of methods, empirical results and directions of future research at the interface of economics and psychology. Carneiro et al. (2007) examine the effect of cognitive and noncognitive skills at the age of 7 on social and labour market outcomes. Their results point to a particularly strong effect of noncognitive skills for individuals with a weak socio-economic background. Cunha and Heckman (2008) estimate a dynamic factor model to explain the formation of cognitive and noncognitive skills depending on parental investments. A major result of their analysis is that parental investments are generally more effective in raising noncognitive skills than cognitive skills. Moreover they find stronger evidence of noncognitive skills promoting the formation of cognitive skills than of the reverse effect. Duncan et al. (2007) focus on the relation between school readiness at school entry age and later school achievements for children in a comparative study for the U.S., U.K. and Canada. Across different samples, besides skills in math and reading at school entry attention skills are the best predictor for educational attainment. For Germany, Blomeyer et al. (2009) provide evidence on the importance of noncognitive skills for school achievement. Their estimates reveal that both IQ and persistence at the age of 8 significantly predict attendance of the Gymnasium after the age of 10. Using German data from the SOEP, Flossmann et al. (2007) 
analyse the effect of noncognitive skills on wages focusing on methodological issues. Uhlendorff (2004) introduces a measure for noncognitive skills into an analysis of unemployment duration. Both Flossmann et al. (2007) and Uhlendorff (2004) find a significant effect of the skill measure on labour market success. In this work we present novel evidence on educational dropout in Germany considering the joint effect of academic and noncognitive skills based on data from the youth questionnaire of the SOEP. In particular, we are able to control for the mother's skills and to observe effects for different age cohorts.

\section{Data source and definitions}

\subsection{The German Socio-Economic Panel}

The German Socio-Economic Panel (SOEP) is a representative national longitudinal data set which surveys households and individuals (Wagner et al.; 2007). In 2007, there were about 11,000 households and more than 20,000 persons sampled in the SOEP. For the empirical investigation we use three sub-samples of the SOEP drawn from eight waves of the years 2000 to 2007.

In our first sample (sample 1) we include all persons aged between 17 and 25 for whom the dropout status is defined, obtaining 21,988 pooled observations. To study the determinants of educational dropout we use information from the youth questionnaire filled in by 17 -year-olds from the year 2000 on. ${ }^{1}$ It provides information on family background like parental education and occupation when the respondents were 15 years old as well as on school achievements, school track and noncognitive skills. The sample also includes information on these individuals from subsequent waves up to 2007. It contains 3,650 observations on individuals at the age between 17 and 21 who were interviewed before $2006 .{ }^{2}$ This sample 2 is a subgroup of sample 1 and the main sample for our econometric investigation. Our third sample is restricted to persons with a sibling aged between 17 and 21 who is also participating in the SOEP and for whom it is possible to observe skill measures and dropout status. It contains 925 observations. We use this sample for additional sensitivity analysis.

\footnotetext{
${ }^{1} \mathrm{~A}$ minority of the individuals have already turned 18 when surveyed.

${ }^{2}$ Because of changes in the questionnaire we do not include the most recent waves from 2006 and 2007 for the definition of items used for our measure of noncognitive skills. But we nevertheless observe some persons in this years who answered these questions in former waves.
} 


\subsection{Definition of educational dropout}

We define educational dropout with respect to the stages at which young people without advanced general education can fail to integrate into the labour market via the German system of general and vocational education. German children normally start school at the age of six and complete four years of primary school and five to six years of lower-level secondary school. ${ }^{3}$ Those who want to earn a degree giving access to higher education complete three more years of upper-level secondary education. The overwhelming majority of schools are public state schools. The secondary schools are traditionally differentiated into three levels, Hauptschule, Realschule and Gymnasium. The first two cover only the lower level of secondary schooling. They are conceived to provide general education as a basis for apprenticeship training or professional schools without university status. The majority of vocational training is provided within the dual system where apprentices work in a firm and go to vocational school part-time for two to three years. For some professions only full-time schooling is provided. Primary and secondary school attendance is compulsory for nine to ten years, depending on the regions (Länder). In most regions three years of part-time schooling in the dual system, or, alternatively three years of full-time general or vocational schooling are compulsory afterwards at least until the age of 18 . While some regions and some school types aim to avoid early ability tracking, most children enter a specific track of secondary school at the age of 10. Primary school teachers recommend a school track for the child, but these recommendations are not binding everywhere.

Nowadays a number of students complete upper-level secondary schooling at Gymnasium before entering an apprenticeship and many graduates of the lowest and even the middle school track encounter problems in entering apprenticeship at all. Special educational measures are targeted at improving these students' preparation for vocational education: the preparation year for vocational training (Berufsvorbereitungsjahr) and the elementary vocational year (Berufsgrundbildungsjahr). The preparation year for vocational training allows students who have left school without any degree to obtain the equivalent of a degree from the lowest track (Hauptschulabschluss) and to prepare for transition into the dual system. The elementary vocational year generally requires a school degree and is offered mainly to students who were unable to enter into the dual system. If the student continues education in the dual system afterwards, the elementary vocational year contributes to the fulfillment of the degree requirements of vocational school.

In our analysis, we generally consider as educational dropouts those who neither are currently in education nor have completed schooling beyond the lower-secondary level. More precisely, a person is considered as an educational dropout if he or she:

\footnotetext{
${ }^{3}$ In some regions, primary school lasts six years and lower-level secondary school three to four.
} 
- left school without any degree, irrespective of subsequent vocational training

- left lower-secondary school without any degree (Hauptschulabschluss, Realschulabschluss or 'mittlere Reife' obtained at Gymansium) and is neither enrolled in vocational education nor holds a vocational degree

- is enrolled in a preparation year for vocational training (Berufsvorbereitungsjahr) or an elementary vocational year (Berufsgrundbildungsjahr)

- is pursuing a degree from lower-level secondary school and is more than two years behind the regular age for obtaining it.

The definition implies that someone who is currently in education may become a dropout if he or she leaves the educational system without a degree. In order to account for the fact that some situations of school enrolment already reflect failed regular integration into the vocational training system, we also count as dropouts those who are more than two years behind the regular age for obtaining a lower-level school degree and still in school as well as those in special measures preparing for vocational training. Someone who obtains a high school degree (Abitur) will by definition not be considered as an educational dropout irrespective of whether he or she completes professional training afterwards.

\subsection{Rotter's Locus of Control}

While the economic literature traditionally recognizes the importance of cognitive skills for school and labour market success, the link between noncognitive skills and human capital accumulation has been studied only in recent years. In school, individuals who have highly pronounced noncognitive skills can e.g. be expected to be motivated in doing homework and less likely to skip school. In the labour market, noncognitive skills influence the willingness to work hard, being on time and being trusted (Heckman and Rubinstein; 2001). They are thus also susceptible to influence the success in entering and completing an apprenticeship.

In our analysis we use Rotter's Locus of Control (Rotter index) as measure for noncognitive skills (Rotter; 1966). The concept developed in psychology identifies noncognitive skills through personality traits. It is employed to distinguish between two types of personality. Respondents are confronted with pairs of opposite statements about their personal situation or life in general. One category of statements sees luck as the determining force of success and failure. The other category sees individual skills and actions as the determining force. According to their degree of agreement with the statements, individuals can be divided into two types, the externaliser and the internaliser. Externalisers attribute outcomes to external circumstances, while internalisers attribute outcomes to their own control. Internalisers are considered to have stronger noncognitive skills such as motivation, interest and self-esteem. 
Table 1: Mean values Rotter's Locus of Control

\begin{tabular}{|c|c|c|c|}
\hline Statement & Dropout & $\begin{array}{l}\text { Non- } \\
\text { dropout }\end{array}$ & t-value \\
\hline I decide the way my life is run & 3.48 & 3.52 & 0.96 \\
\hline $\begin{array}{l}\text { Compared to others, I haven't attained what I } \\
\text { deserve }\end{array}$ & 2.80 & 3.11 & 6.86 \\
\hline $\begin{array}{l}\text { What you achieve in life is mainly a matter of fate } \\
\text { or luck }\end{array}$ & 2.56 & 2.82 & 5.62 \\
\hline Experience that others determine my life & 2.27 & 2.39 & 2.50 \\
\hline In case of difficulties doubts about own abilities & 2.63 & 2.93 & 6.44 \\
\hline Little control over life & 3.46 & 3.44 & -0.67 \\
\hline One has to work hard to achieve success & 2.48 & 2.75 & 5.87 \\
\hline Possibilities limited by social conditions & 2.14 & 2.36 & 4.91 \\
\hline Abilities are more important than effort & 1.94 & 2.02 & 1.93 \\
\hline $\begin{array}{l}\text { Social and political activities influence social con- } \\
\text { ditions }\end{array}$ & 2.91 & 3.15 & 5.43 \\
\hline Locus of Control (all statements) & 26.69 & 28.48 & 9.76 \\
\hline Observations & 304 & 3,346 & \\
\hline
\end{tabular}

Source: SOEP 2000-2007. Own calculation, sample 2. The scale ranges from 10 to 40. High levels indicate strong noncognitive skills (internalisers), low levels indicate weak noncognitive skills (externalisers).

In order to construct a Rotter index we use 10 items from the youth questionnaire. The items are ranked on a four-point scale in the youth questionnaire and are addressed to all 17-year-olds. We sum up all items to obtain a unidimensional scale. Table 1 presents the means for all items and the overall noncognitive skill indicator (Rotter index), separately for educational dropouts and other individuals. Additionally, we compute t-tests to examine whether these groups differ significantly with respect to noncognitive skills. The results indicate that educational dropouts have significantly lower noncognitive skills than non-dropouts (see also Figure 2). The standard deviation of the overall distribution of the Rotter index is 3.1 points.

In addition, in 2005 the Rotter index was assessed for all adults, which include the individuals' mothers (Because the number of missing observations is higher for fathers, we have not included them). This measure covers the same items as the one in the youth questionnaire, but the scale ranges from 1 to 7 for each item. The SOEP is one of the rare representative data sets containing measures of noncognitive skills for both, mothers and children. We merge the mother's noncognitive skills to the child's skills at the age of 17 . In doing so we assume that a mother's noncognitive skills are relatively stable during 2000 to 2007 (see e.g. Dahl (2004) for evidence on stability of personality traits from early adulthood on). 
Figure 2: Locus of Control for 17-year-olds

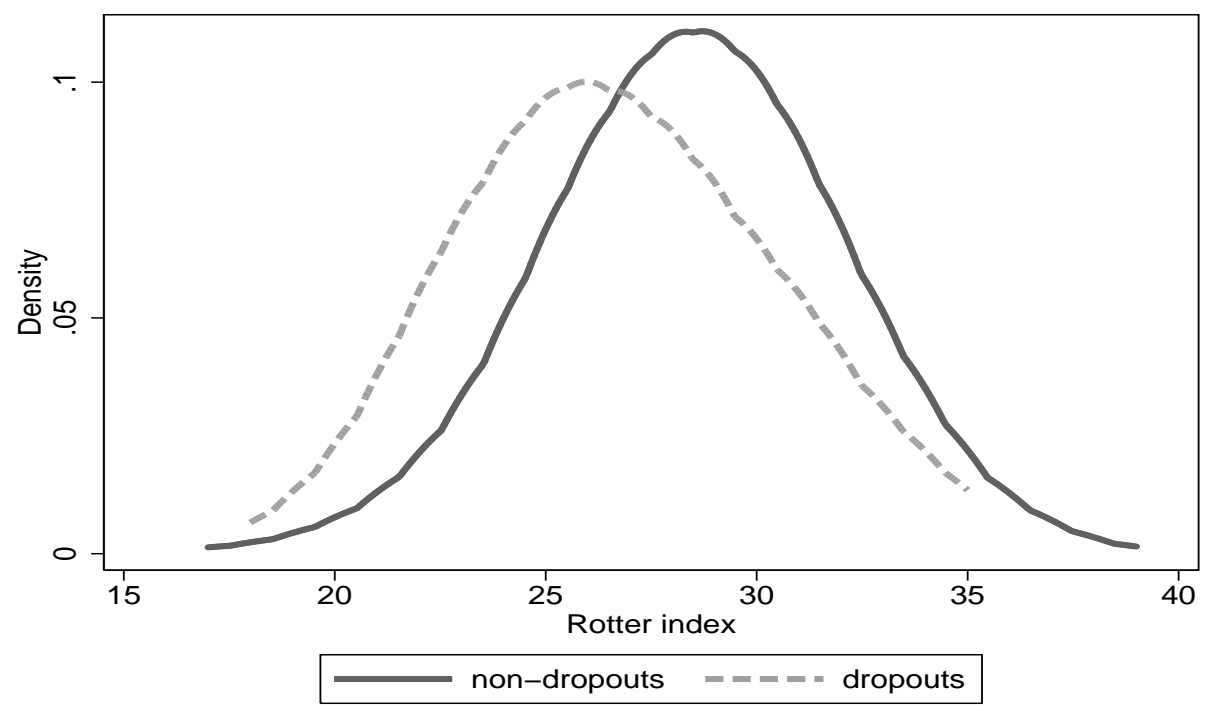

Source: SOEP 2000-2007. Own calculation, sample 2.

\subsection{School achievements}

In examining the effect of noncognitive skills at the age of 17 on educational dropout in the same and subsequent years, it is necessary to distinguish between two effects: their direct effect on being motivated to finish school and to find an apprenticeship, and the effect from their likely positive association with cognitive skills and school achievements in particular subjects. We do not observe cognitive skills in the form of IQ-tests or general academic performance tests as available e.g. in the PISA survey. Meanwhile the data set contains information on the last school grades obtained in mathematics and German. The grades adjusted for school track are the measure of academic skills and school achievements available for our analysis. Academic skills are likely to depend on cognitive skills, noncognitive skills and educational investments.

The persons in the youth sample are attending different school tracks. We generate a universal score to compare the grades in math and German across school tracks. Grades in Germany range from 1 to 6 with 1 to 4 being pass grades and 5 and 6 being fail grades. The 17-year-old individuals are asked about the last grades they got in school at the end of a semester. For some of them these will be final school leaving grades, others will still be in the course of pursuing a degree. To make grades comparable across school tracks, we look at conditions for admission to a higher school track in the case of good grades. To some extent, the Länder (regions) provide regulations how teachers should decide about this transfer. In general a grade average between 2 and 3 is necessary for being recommended for a 
higher school track. ${ }^{4}$ Some regulations require the grade 2 in most main subjects (math, German, first foreign language). So the most plausible way to make grades comparable is to assume that 2 at the lower school track corresponds to a pass grade (4) in the higher school track. Assuming further that the relation is linear (3 at the lower track corresponding to 5 at the higher one etc.), we obtain ten grade levels in two subjects. We generate a composite score ranging from 2 to 20 . It is obtained subtracting the sum of grades from 22 and subtracting 2 for a grade obtained in the middle school track and 4 for a grade obtained in the lowest school track. The assumptions about comparability of grades may seem to be quite strong. But a measure of school grades confers essential information on possible determinants of educational dropout that cannot be omitted in a case where a measure of cognitive skills is not available. Figure 3 shows that the grade score distribution of the dropout group is located at the left of the distribution of the non-dropouts. The mean score is 13.11 for non-dropouts and 9.61 for dropouts. This relation also holds for subgroup 3 (see Table 2). The standard deviation of the overall distribution of the grade score is 3.7 points.

Figure 3: Distribution of the score of school grades for 17-year-olds

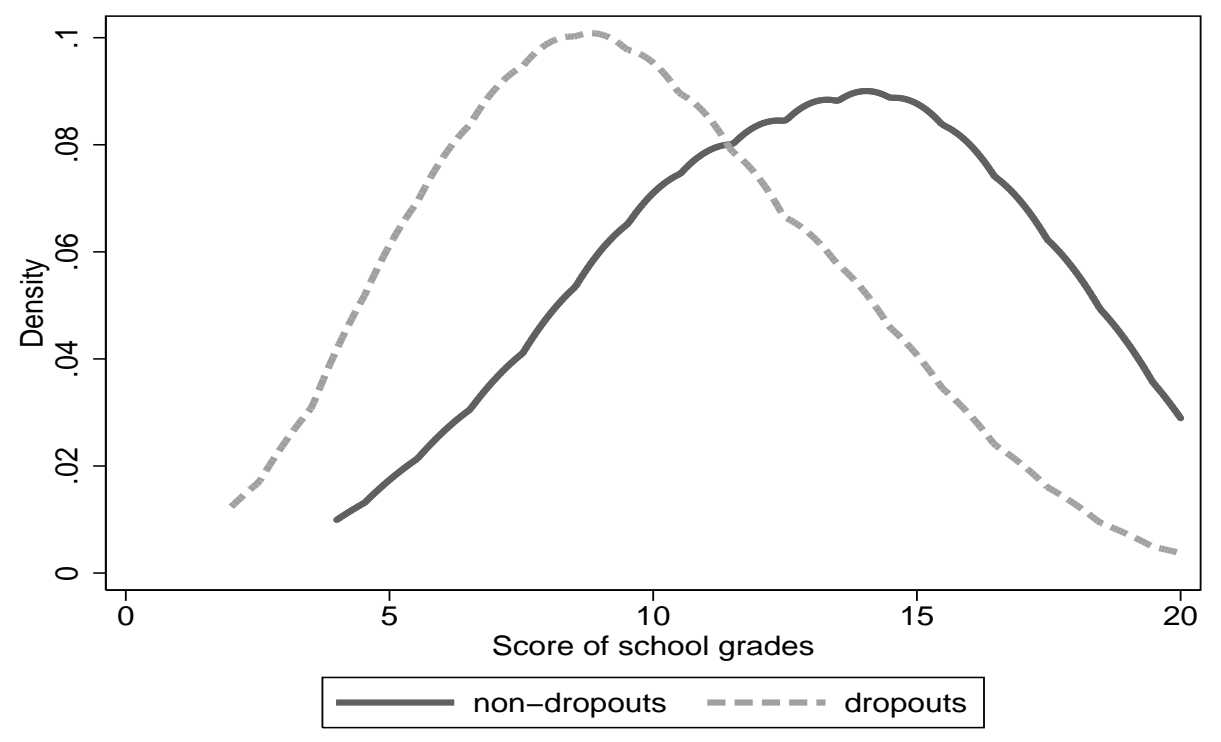

Source: SOEP 2000-2007. Own calculation, sample 2.

\footnotetext{
${ }^{4}$ See e.g. Bayerisches Staatsministerium für Unterricht und Kultus (2008), Senatsverwaltung für Bildung, Wissenschaft und Forschung des Landes Berlin (2005) and Ministerium für Schule und Weiterbildung des Landes Nordrhein-Westfalen (2008).
} 


\section{Determinants of educational dropout}

\subsection{Descriptive statistics}

Table 2 reports descriptive statistics for the three samples used by dropout status. It contains sample means of all variables used in the estimation. The share of dropouts varies between $8 \%$ for sample 2 and $10 \%$ for sample 1.

Dropouts are older in all samples. Also the share of persons with migration background is about ten percentage points higher for dropouts. The migration share is highest in sample 3 . This could be caused by a higher probability to observe siblings in immigrant families. ${ }^{5}$

The share of females is higher for non-dropouts in sample 1 and 2 . In the lower part of Table 2 we look at descriptive statistics for the family background, especially the mother's characteristics, which we use in the estimations based on this sample. Information on the mother's education and occupational status refers to characteristics when individuals were 15 years old. The overall pattern is that on average maternal educational attainment is lower than the attainment of the offspring. While $79 \%$ of the non-dropouts lived together with both of their parents at age 15 this share is only $65 \%$ for dropouts. In several categories of education a clear picture emerges of mothers of non-dropouts being better educated than mothers of dropouts. The share of mothers working as a white-collar employee is nearly twice as high for non-dropouts compared to dropouts.

Between the age of 18 and 25, the overall share of dropouts increases only slightly (see Figure 4). But at the individual level one observes nonnegligible rates of entry to the dropout status and exit from it in the late teens and early twenties. There is the possibility of definite exit by earning the corresponding degrees. Given the German system of general and professional education, causes for entering and exiting the dropout status vary between age cohorts. For this reason we do not attempt to model the time spells of being a dropout. But still it is interesting to see the evolution of entry and exit rates over age cohorts. Considering those in the sample of 17 - to 25-year-olds we observe that entry rates are almost continuously declining from the age of 18 on, while exit rates decline from the age of 19 on (see Table 3). Further the reason of being a dropout changes over time. In younger ages having no school degree is the main reason to become a dropout while later failure to enter or complete a vocational degree is for nearly 90 percent of the group of dropouts responsible for this status (see Figure 5).

\footnotetext{
${ }^{5}$ The dummy for immigration takes the value one if the individual belongs to the first or second generation of immigrants and zero otherwise.
} 
Table 2: Descriptive statistics by dropout status

\begin{tabular}{|c|c|c|c|c|c|c|}
\hline & \multicolumn{2}{|c|}{ Sample 1} & \multicolumn{2}{|c|}{ Sample 2} & \multicolumn{2}{|c|}{ Sample 3} \\
\hline & $\begin{array}{l}\text { Non- } \\
\text { Dropout }\end{array}$ & Dropout & $\begin{array}{l}\text { Non- } \\
\text { Dropout }\end{array}$ & Dropout & $\begin{array}{l}\text { Non- } \\
\text { Dropout }\end{array}$ & Dropout \\
\hline Dropout ratio & \multicolumn{2}{|c|}{0.10} & \multicolumn{2}{|c|}{0.08} & \multicolumn{2}{|c|}{0.09} \\
\hline West German share & 0.72 & 0.78 & 0.70 & 0.68 & 0.72 & 0.66 \\
\hline Female Share & 0.51 & 0.48 & 0.52 & 0.40 & 0.52 & 0.53 \\
\hline Age & 20.91 & 21.29 & 18.45 & 18.73 & 18.22 & 18.52 \\
\hline Migration background & 0.19 & 0.31 & 0.18 & 0.28 & 0.23 & 0.35 \\
\hline Rotter index & & & 28.48 & 26.69 & 28.21 & 26.31 \\
\hline Grade score & & & 13.11 & 9.61 & 12.47 & 8.52 \\
\hline Rotter index, mother & & & 45.09 & 42.40 & & \\
\hline Family lives together & & & 0.79 & 0.65 & & \\
\hline \multicolumn{7}{|c|}{ Education and occupational status of the mother } \\
\hline Low or no school degree & & & 0.41 & 0.69 & & \\
\hline Medium school degree & & & 0.43 & 0.26 & & \\
\hline High school degree & & & 0.16 & 0.05 & & \\
\hline No training qualification & & & 0.13 & 0.28 & & \\
\hline Apprenticeship degree & & & 0.62 & 0.63 & & \\
\hline Higher apprenticeship degree & & & 0.05 & 0.01 & & \\
\hline University degree & & & 0.20 & 0.08 & & \\
\hline Not working & & & 0.22 & 0.40 & & \\
\hline Blue-collar worker & & & 0.21 & 0.30 & & \\
\hline White-collar worker & & & 0.44 & 0.24 & & \\
\hline Self-employed & & & 0.07 & 0.05 & & \\
\hline Civil-servant & & & 0.06 & 0.01 & & \\
\hline \multirow[t]{2}{*}{ Observations } & \multicolumn{2}{|c|}{21,988} & \multicolumn{2}{|c|}{3,650} & \multicolumn{2}{|c|}{925} \\
\hline & 19,274 & 2,264 & 3,346 & 304 & 840 & 85 \\
\hline
\end{tabular}

Source: SOEP 2000-2007. Own calculation. 
Table 3: Dropout status

\begin{tabular}{lllll}
\hline \hline Age & $\begin{array}{l}\text { Stayed } \\
\text { non-dropout }\end{array}$ & Stayed dropout & Exit dropout & Entry dropout \\
\hline 18 & 85.8 & 2.6 & 2.9 & 8.6 \\
19 & 84.5 & 4.6 & 5.5 & 5.4 \\
20 & 85.7 & 5.8 & 4.2 & 4.2 \\
21 & 85.2 & 7.1 & 2.9 & 4.8 \\
22 & 85.9 & 8.2 & 2.3 & 3.6 \\
23 & 86.5 & 8.9 & 1.7 & 2.9 \\
24 & 87.1 & 10.2 & 1.1 & 1.6 \\
25 & 87.7 & 10.5 & 0.7 & 1.1 \\
\hline \hline
\end{tabular}

Source: SOEP 2000-2007. Own calculation, sample 1. Shares in percent.

Figure 4: Distribution of educational dropouts over age cohorts

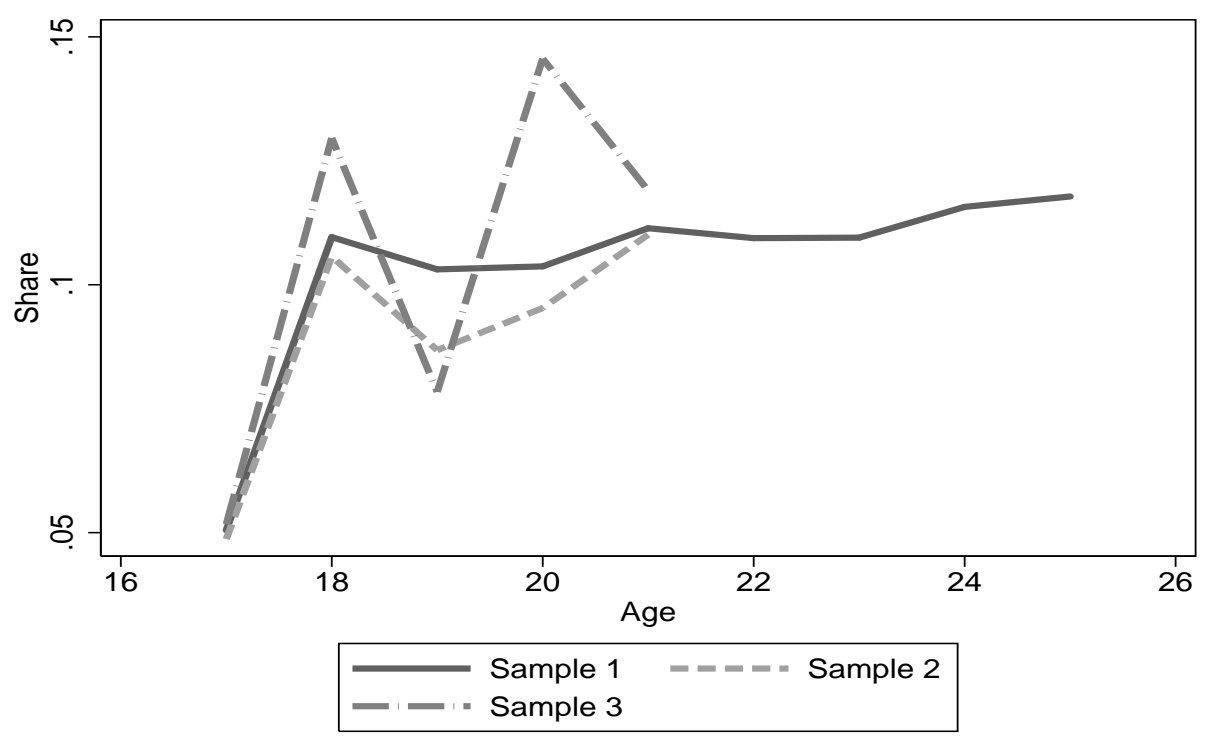

Source: SOEP 2000-2007. 
Figure 5: Reason for dropout status over age cohorts

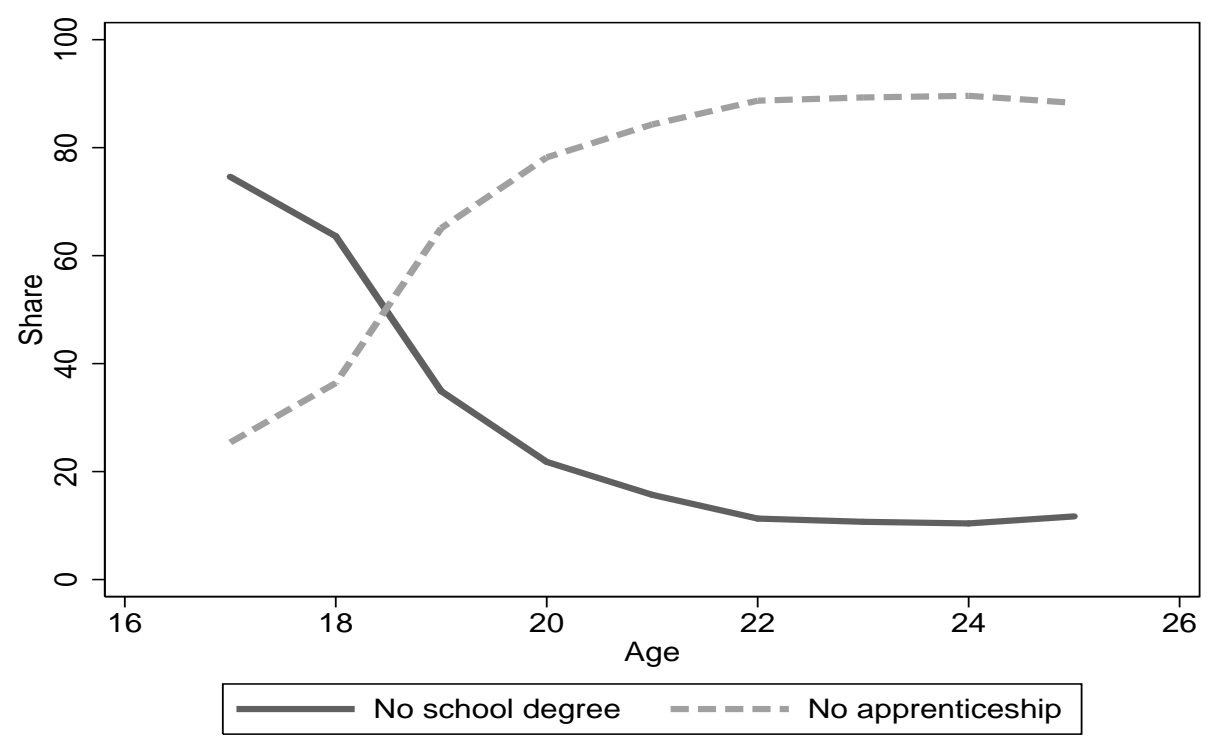

Source: SOEP 2000-2007. Own calculation, sample 1.

\subsection{Empirical approach}

Our goal is to assess the role school grades and noncognitive skills play in reducing the risk of educational dropout from lower-level secondary and vocational education. School grades to some extent predetermine the chances to become an educational dropout since bad school grades in the lower tracks of secondary school typically precede educational dropout as we have defined it. But there exist a number of measures for weak students to obtain a degree after initial failure. On the other hand, initially good grades cannot fully prevent from becoming an educational dropout if the student loses motivation. Moreover, school grades mainly reflect academic skills (and we will use this term to refer to it in the economic model). The system of vocational education might relatively stronger value other skills such as self-control and self-confidence, which we consider explicitly, or manual skills.

Academic and noncognitive skills are known to depend on family characteristics and investments to skill formation. Previous research also suggests that academic skills measured through school grades depend on both cognitive and noncognitive skills. The major advantage of our sample is that it contains measures of academic and noncognitive skills of both the young women and men and their mothers. Data are also available for fathers, but with higher share of missing observations, so we have not included them. The sample does not contain measures of cognitive skills.

A number of factors that influence academic and noncognitive skills will additionally affect dropout risk. Even at constant school grades, someone with higher cognitive skills might be more likely to enter an apprenticeship. Or someone with better 
educated parents may obtain better support in choosing an occupation and applying for an apprenticeship. We attempt to account for the endogeneity of skill measures potentially arising from these relations following different approaches. First we consider how the effect of academic and noncognitive skills on the probability of being a dropout changes once we control for the mother's skills and other covariates. Then we consider school track recommendation after primary school and stress with parents about school performance as instrumental variables for academic skills. Finally we obtain more direct evidence on the effect of skills on educational dropout at constant family background in estimating a panel model for siblings.

We observe the Rotter index as a measure of noncognitive skills and the last school grades obtained as a measure of academic skills at the age of 17 . Dropout status is observed in this and up to seven subsequent periods, but because of small sample sizes in the oldest cohorts we limit our econometric analysis to cohorts aged 17 to 21. Since the explanatory variables do not vary over time, we estimate models for single cohorts or pooled samples rather than dynamic panel models. Over the period considered, the influence of different variables on the dropout status can be expected to vary.

\subsection{Simple probit models}

We first estimate a probit model for dropout status of individual $i$ at a certain age only including the measures for academic and noncognitive skills, $a c_{i}$ and $n_{i}$ :

$$
\operatorname{Prob}\left(\text { dropout }_{i}\right)=f\left(\alpha+\beta_{a c} a c_{i}+\beta_{n} n_{i}\right),
$$

$f$ representing the normal density function in this paragraph.

Table 4: Probit estimation educational dropout

\begin{tabular}{llllll}
\hline \hline & $\mathbf{1 7}$ years & $\mathbf{1 8}$ years & $\mathbf{1 9}$ years & 20 years & 21 years \\
\hline Grade score & $-0.014^{* * *}$ & $-0.027^{* * *}$ & $-0.015^{* * *}$ & $-0.014^{* * *}$ & $-0.013^{* * *}$ \\
& $(0.002)$ & $(0.003)$ & $(0.003)$ & $(0.004)$ & $(0.005)$ \\
Rotter index & $-0.004^{*}$ & $-0.008^{* * *}$ & $-0.010^{* * *}$ & $-0.012^{* * *}$ & $-0.021^{* * *}$ \\
& $(0.002)$ & $(0.003)$ & $(0.003)$ & $(0.004)$ & $(0.005)$ \\
\hline Pseudo- $R^{2}$ & 0.19 & 0.22 & 0.11 & 0.10 & 0.13 \\
Sample size & 1,108 & 908 & 772 & 535 & 327 \\
\hline \hline
\end{tabular}

Notes: Average marginal effects. Standard errors are in parentheses: ${ }^{* * *}$ significant at $1 \%,{ }^{* *}$ at $5 \%$ and $* 10 \%$ level.

Source: SOEP 2000- 2007. Own calculation, sample 2.

We observe that the average effect of school grades on the probability to be a dropout peaks with 18 years and declines afterwards (see Table 4). The effect of the Rotter index on the dropout probability continuously increases with age. 
In order to reduce unobserved heterogeneity likely to affect the estimates of $\beta_{a c}$ and $\beta_{n}$, we include measures of the mother's noncognitive skills $n_{m}$ (individual $i$ 's mother being index by $m$ ), of her academic and professional achievement $a c_{m}$ and other covariates $x_{i}$ to the model (For details on the dummy variables see section 4.1):

$$
\operatorname{Prob}\left(\text { dropout }_{i}\right)=f\left(\alpha+\beta_{a c} a c_{i}+\beta_{n} n_{i}+\gamma_{a c} a c_{m}+\gamma_{n} n_{m}+\gamma_{x} x_{i}\right) .
$$

Introducing the full set of covariates reduces the effect of school grades on the probability of being a dropout by a fifth to a half (see Table 5). The effect of the Rotter index is only slightly reduced for some cohorts. The effect of the mother's Rotter index is virtually zero. The pattern of effects over the ages remains the same. We interpret this pattern as reflecting the different stages of failure in transition from school to completed vocational training. At the age of 17, the share of dropouts is still low (see Figure 5), because some that will eventually not obtain their school degree have not yet failed. At the age of 18 , the share of dropouts increases sharply, reflecting dropout of school and failed transition into apprenticeship immediately after obtaining a degree. Both plausibly depend on school grades. At later ages, educational dropout depends on ongoing failure to enter an apprenticeship and dropout or failure during apprenticeship. The share of those being a dropout not because of failure at school but because of failure to enter or complete the system of vocational training rises. During this stage, noncognitive skills seem to play an increasingly important role. Since noncognitive skills are measured at the age of 17 we are able to exclude that this effect results from reverse causality.

In order to verify that age effects do not depend on differences in samples across cohorts, we compare the pooled sample 2 with the subset of individuals which are observed in all five periods (balanced sample). Moreover we consider the siblings sample that will be used for panel estimation in section 4.5. We see that interaction terms between skill measures and age are significant in both sample 2 and the smaller balanced sample. In the latter the interaction effect for the Rotter index is even somewhat larger. Meanwhile interaction effects with age are insignificant in the siblings sample (see Table 6).

In sum, the effects of skills on the dropout status are not much reduced when controlling for the mother's skills and other variables. With regard to their magnitude, we consider the estimates for single cohorts aged 18 to 20 as most reliable. In the cohort of 17-year-olds, the share of dropouts is still small, and for 21-year-olds, the sample is particularly small and the marginal effects of the Rotter index and the dummy for migration background change notably. For the 18- to 20-year-olds the effect of a one point higher grade score on the dropout probability ranges between 0.8 and 2.3 percentage points. An individual whose grade score is one standard deviation higher (3.7 points) has on average a probability to be an educational dropout that is between 3.0 and 8.5 percentage points lower. Lying just 
Table 5: Probit estimation educational dropout, with control variables

\begin{tabular}{llllll}
\hline \hline & $\mathbf{1 7}$ years & $\mathbf{1 8}$ years & $\mathbf{1 9}$ years & 20 years & 21 years \\
\hline Grade score & $-0.015^{* * *}$ & $-0.023^{* *}$ & $-0.010^{* * *}$ & $-0.008^{* *}$ & -0.006 \\
& $(0.002)$ & $(0.003)$ & $(0.003)$ & $(0.004)$ & $(0.005)$ \\
Rotter index & $-0.004^{*}$ & $-0.007^{* *}$ & $-0.008^{* *}$ & $-0.012^{* * *}$ & $-0.023^{* * *}$ \\
& $(0.002)$ & $(0.003)$ & $(0.003)$ & $(0.004)$ & $(0.005)$ \\
\hline Rotter index mother & 0.000 & 0.000 & 0.000 & 0.000 & 0.001 \\
& $(0.001)$ & $(0.001)$ & $(0.001)$ & $(0.001)$ & $(0.002)$ \\
Female & -0.006 & 0.009 & -0.027 & $-0.049^{*}$ & -0.040 \\
Family together & $(0.013)$ & $(0.019)$ & $(0.019)$ & $(0.026)$ & $(0.033)$ \\
\multirow{2}{*}{ Migration background } & $-0.034^{* *}$ & $-0.054^{* *}$ & -0.023 & -0.005 & -0.024 \\
& $(0.017)$ & $(0.024)$ & $(0.024)$ & $(0.032)$ & $(0.042)$ \\
Education mother & 0.009 & $0.078^{* *}$ & -0.014 & -0.001 & $-0.072^{* *}$ \\
West & $(0.018)$ & $(0.031)$ & $(0.027)$ & $(0.034)$ & $(0.036)$ \\
\hline Pseudo- $R^{2}$ & yes & yes & yes & yes & yes \\
Sample size & yes & yes & yes & yes & yes \\
\hline \hline Notes: Average & 0.22 & 0.27 & 0.17 & 0.14 & 0.25 \\
\hline
\end{tabular}

Notes: Average marginal effects. Standard errors are in parentheses: ${ }^{* * *}$ significant at $1 \%,{ }^{* *}$ at $5 \%$ and $* 10 \%$ level.

Source: SOEP 2000- 2007. Own calculation, sample 2.

below 4 points the standard deviation roughly corresponds to having good grades instead of passing grades in the two subjects considered or to obtaining the same grades at the next higher school track. In the same cohorts, the average marginal effect of a one point increase in the Rotter index on the probability to be a dropout lies between 0.7 and 1.2 percentage points. This implies that a standard deviation difference in noncognitive skills (3.1 points) is related to a dropout probability that is 2.2 to 3.7 percentage points lower. 
Table 6: Probit estimation educational dropout, pooled sample

\begin{tabular}{|c|c|c|c|}
\hline & Sample 2 & Balanced sample & Siblings sample \\
\hline \multirow[t]{2}{*}{ Grade score } & $-0.020^{* * *}$ & $-0.023^{* * *}$ & $-0.026^{* * *}$ \\
\hline & $(0.002)$ & $(0.006)$ & $(0.005)$ \\
\hline \multirow[t]{2}{*}{ Rotter index } & -0.004 & -0.006 & $-0.012^{* * *}$ \\
\hline & $(0.003)$ & $(0.007)$ & $(0.004)$ \\
\hline \multirow[t]{2}{*}{ Grade score $*$ age } & $0.004^{* * *}$ & $0.004^{* *}$ & 0.002 \\
\hline & $(0.001)$ & $(0.002)$ & $(0.003)$ \\
\hline \multirow[t]{2}{*}{ Rotter index $*$ age } & $-0.002^{* *}$ & $-0.004^{*}$ & 0.003 \\
\hline & $(0.001)$ & $(0.002)$ & $(0.002)$ \\
\hline \multirow[t]{2}{*}{ Age } & $0.016^{* * *}$ & 0.006 & $0.031^{* * *}$ \\
\hline & $(0.004)$ & $(0.008)$ & $(0.011)$ \\
\hline \multirow[t]{2}{*}{ Rotter index mother } & 0.000 & -0.001 & 0.002 \\
\hline & $(0.001)$ & $(0.002)$ & $(0.002)$ \\
\hline \multirow[t]{2}{*}{ Female } & -0.016 & $-0.090^{* * *}$ & 0.025 \\
\hline & $(0.011)$ & $(0.021)$ & $(0.030)$ \\
\hline \multirow[t]{2}{*}{ Family together } & $-0.032^{* *}$ & -0.026 & 0.002 \\
\hline & $(0.017)$ & $(0.035)$ & $(0.032)$ \\
\hline \multirow[t]{2}{*}{ Migration background } & 0.015 & -0.007 & 0.025 \\
\hline & $(0.016)$ & 0.042 & $(0.039)$ \\
\hline Education mother & yes & yes & yes \\
\hline West & yes & yes & yes \\
\hline Pseudo- $R^{2}$ & 0.19 & 0.23 & 0.28 \\
\hline Sample size & 3,650 & 900 & 735 \\
\hline
\end{tabular}

Notes: Average marginal effects. Standard errors are in parentheses, clustered for individuals: $* * *$ significant at $1 \%, * *$ at $5 \%$ and $* 10 \%$ level.

Source: SOEP 2000- 2007. Own calculation, sample 2, reduced sample 2 with individuals observed in 5 periods and sample 3 reduced to observations with the full set of covariates.

\subsection{Instrumental variable models}

Skills and dropout status may be subject to correlated unobserved effects, even after controlling for the background variables included in the probit regression. In this case academic or noncognitive skills are endogenous and depend on the same unobserved effects that influence educational dropout. Any model that will introduce academic or noncognitive skills as endogenous regressors has to consider as a starting point the regression of skill measures on exogenous covariates and potential instrumental variables (see Table 7).

Usually the instruments that find the strongest argumentative support result from natural experiments or institutional regulations affecting otherwise similar populations in different ways. In this analysis we are not able to recur to such an instrumental variable. Another difficulty is that we have to deal with two 
potentially endogenous skill measures. So the results have to be read with a caveat in mind. The first instrument we consider for academic skills is the school recommendation after primary school. The variable in the data set indicates whether a person obtained a recommendation for one of the three secondary school tracks or did not obtain any recommendation. How binding these recommendations are varies across regions and years. We define a dummy variable that takes the value 1 if someone obtained a recommendation to enter the Hauptschule, the lowest track, and zero, if he obtained another or no recommendation. Out of those who obtained a recommendation for the Hauptschule, $71 \%$ attended it up to leaving school or were still attending it at the age of 17 . Of those who did not obtain this recommendation, $15 \%$ attended the Hauptschule as last school. We argue that once two individuals have attained equal school achievement, the recommendation for the Hauptschule does not have any independent effect on the probability of being a dropout. As a second instrument for school achievement we consider the response to the question whether the person has ever had 'differences in opinion' about school performance with his or her parents. Certainly this dummy variable is not causing lower school grades, but it is correlated with them, while it is unlikely to be related to dropout risk except through school grades. For the individuals' Rotter index it is hard to find any instruments. In fact, the first stage regression shows that it displays little correlation with any variable so far included in the model except the mother's Rotter index and the dummy for her being a civil servant. So the mother's Rotter index seems the only candidate for an instrument, assuming that it has no direct effect on the probability to be a dropout.

The t-statistics of the instruments suggest that they are indeed correlated with the endogenous regressors. But the overall fit of the reduced-form equation for the individual's Rotter index is quite low. As a result, estimating IV or three-stageleast squares models with both forms of skills as endogenous variables yields an insignificant coefficient for the Rotter index and its endogeneity can be rejected at high probabilities. ${ }^{6}$ So from a statistical point of view we consider an individual's noncognitive skills as exogenous. Thus we estimate equation (2) using instruments $\mathbf{z}_{i}$ with $\operatorname{cov}\left(a c_{i}, \mathbf{z}_{i}\right) \neq 0$ and assumed to satisfy $E\left[u_{i} \mid \mathbf{z}_{i}\right]=0$.

In order to explicitly allow for the nonlinearity of the model, one would have to resort to structural modeling placing strong restrictions on the error term or to computationally more demanding nonlinear IV methods. Since the linear probability model usually yields a good approximation for the average marginal effects on a binary variable, an ordinary linear model and a linear instrumental variables model using GMM are estimated (see Table 8). The efficiency loss associated with instrumental variable regression increases standard errors in a way that will make

\footnotetext{
${ }^{6}$ Results available upon request.
} 
many estimates for individual cohorts based on small samples insignificant. The analysis is therefore restricted to the pooled sample 2. Missing observations for instruments reduce the sample size slightly. Because of the difficulty of identifying the effects of two collinear endogenous regressors, we do not include the interaction term between school grades and age.

Introducing the first instrument only, we would not reject the exogeneity of school grades. In the more efficient estimation with two instruments, exogeneity is rejected at the $10 \%$ level (see second and third column of Table 8). The interaction term between the Rotter index and age remains unchanged and significant after allowing for endogeneity of school grades. The coefficient of school grades itself rises in absolute value, which may seem counterintuitive at first sight. If school grades were positively correlated with unobserved ability that reduces the risk of being a dropout, one would expect that the coefficient declines in absolute value if the bias is reduced. One possibility is that the instruments are not suitable. But there may also be a plausible reason for this effect. Unobserved factors rising dropout risk such as low manual skills, an instable personal situation or being in a location with a bad labour market may matter more for people with intermediate academic skills than for people with low academic skills. The latter may have a very high dropout risk anyway and additional adverse factors may not make things much worse. The effect of unobserved adverse conditions may be stronger for individuals with intermediate academic skills. So holding the effect of these conditions constant would eliminate a downward bias in the absolute value of the coefficients for school grades. Accounting for endogeneity raises the average effect of a grade score that is by one standard deviation (3.7 points) on the probability to be a dropout from 5.5 percentage points to 8.9 percentage points. 
Table 7: Reduced form OLS estimation of skill measures

\begin{tabular}{|c|c|c|}
\hline & Grade score & Rotter index \\
\hline \multirow[t]{2}{*}{ School recommendation } & $-3.440 * * *$ & $\mathrm{x}$ \\
\hline & $(0.261)$ & \\
\hline \multirow[t]{2}{*}{ Disagreements school perf. } & $-1.139 * * *$ & $\mathrm{x}$ \\
\hline & $(0.187)$ & \\
\hline \multirow[t]{2}{*}{ Rotter index mother } & $\mathrm{x}$ & $0.109 * * *$ \\
\hline & & $(0.013)$ \\
\hline \multirow[t]{2}{*}{ Female } & $0.824^{* * *}$ & -0.233 \\
\hline & $(0.186)$ & $(0.185)$ \\
\hline \multirow[t]{2}{*}{ Family together } & $0.822^{* * *}$ & -0.029 \\
\hline & $(0.230)$ & $(0.219)$ \\
\hline \multirow[t]{2}{*}{ Migration background } & 0.338 & 0.027 \\
\hline & $(0.295)$ & $(0.285)$ \\
\hline \multirow[t]{2}{*}{ West Germany } & -0.147 & 0.042 \\
\hline & $(0.219)$ & $(0.229)$ \\
\hline \multicolumn{3}{|c|}{ Education and occupational status of the mother } \\
\hline \multirow[t]{2}{*}{ Low or no school degree } & $-1.859^{* * *}$ & -0.438 \\
\hline & $(0.334)$ & $(0.335)$ \\
\hline \multirow[t]{2}{*}{ Medium school degree } & $-0.772^{* *}$ & -0.078 \\
\hline & $(0.325)$ & $(0.329)$ \\
\hline \multirow[t]{2}{*}{ No vocational degree } & $-1.828^{* * *}$ & -0.215 \\
\hline & $(0.426)$ & $(0.430)$ \\
\hline \multirow[t]{2}{*}{ Mother apprenticeship degree } & $-1.519 * * *$ & -0.107 \\
\hline & $(0.288)$ & $(0.327)$ \\
\hline \multirow[t]{2}{*}{ Higher apprenticeship degree } & -0.572 & 0.381 \\
\hline & $(0.482)$ & $(0.512)$ \\
\hline \multirow[t]{2}{*}{ Blue-collar worker } & -0.201 & 0.133 \\
\hline & $(0.289)$ & $(0.269)$ \\
\hline \multirow[t]{2}{*}{ White-collar worker } & $0.682^{* * *}$ & 0.262 \\
\hline & $(0.257)$ & $(0.244)$ \\
\hline \multirow[t]{2}{*}{ Self-employed } & $1.096^{* * *}$ & $0.676^{*}$ \\
\hline & $(0.377)$ & $(0.391)$ \\
\hline \multirow[t]{2}{*}{ Civil servant } & 0.538 & 0.152 \\
\hline & $(0.435)$ & $(0.481)$ \\
\hline$R^{2}$ & 0.364 & 0.094 \\
\hline Number of observations & 3576 & 3576 \\
\hline
\end{tabular}

Notes: Standard errors are in parentheses, clustered for individuals: ${ }^{* * *}$ significant at $1 \%,{ }^{*} *$ at $5 \%$ and $* 10 \%$ level.

Source: SOEP 2000- 2007. Own calculation, sample 2. Reference categories of the dummies for the mother are the highest educational categories and the category of non-working mothers. 
Table 8: IV estimation educational dropout

\begin{tabular}{llll}
\hline \hline & OLS & IV GMM & $\begin{array}{l}\text { IV GMM with 2 instru- } \\
\text { ments }\end{array}$ \\
\hline \hline Grade score & $-0.015^{* * *}$ & $-0.022^{* * *}$ & $-0.024^{* * *}$ \\
Rotter index & $(0.002)$ & $(0.007)$ & $(0.006)$ \\
& -0.004 & -0.003 & -0.002 \\
Rotter*age & $(0.002)$ & $(0.003)$ & $(0.002)$ \\
& $-0.003^{* * *}$ & $-0.003^{* * *}$ & $-0.003^{* * *}$ \\
Age & $(0.001)$ & $(0.001)$ & $(0.001)$ \\
& $0.011^{* * *}$ & $0.011^{* * *}$ & $0.011^{* * *}$ \\
\hline Female & $(0.004)$ & $(0.004)$ & $(0.004)$ \\
& -0.018 & -0.009 & -0.008 \\
Family together & $(0.013)$ & $(0.013)$ & $(0.013)$ \\
& $-0.036^{* *}$ & -0.029 & -0.026 \\
Migration background & $(0.018)$ & $(0.019)$ & $(0.018)$ \\
& 0.016 & 0.018 & 0.019 \\
Education mother & $(0.020)$ & $(0.021)$ & $(0.021)$ \\
West & yes & yes & yes \\
\hline$R^{2}$ & yes & yes & yes \\
p-value Chi ${ }^{2}$ exogeneity & 0.103 & 0.096 & 0.092 \\
p-value Hansen's J overid. & & 0.304 & 0.088 \\
F-value first stage & & & 0.688 \\
excluded instruments & & 163.11 & 105.48 \\
Number of observations & 3,576 & 3,576 & 3,576 \\
\hline \hline
\end{tabular}

Notes: Standard errors are in parentheses, clustered for individuals: ${ }^{* * *}$ significant at $1 \%,{ }^{* *}$ at $5 \%$ and $* 10 \%$ level.tSource: SOEP 2000- 2007. Own calculation, sample 2 . 


\subsection{Models with unobserved family effects for siblings}

An alternative to instrumental variables in tackling the problem of causal inference is to study the educational dropout status of siblings $(i \in\{1,2,3\})$ in family $j$ observed at the same age. The general panel model is

$$
P\left(\text { dropout }_{i j}\right)=f\left(\text { family }_{j}+\beta_{a c} a c_{i j}+\beta_{n} n_{i j}\right) .
$$

If siblings are affected identically by the family background family $f_{j}$ and there is no heterogeneity in skill effects $\beta_{a c}$ and $\beta_{n}$, the model will recover an asymptotically unbiased estimate under suitable assumptions about the distribution of family $_{j}$. Observing siblings in general instead of twins we consider a more representative sample of individuals, but we risk to obtain biased estimates because of differences in genetic endowment and changes in family conditions between births. In each estimation the siblings are observed at the same age. Since data on siblings are very limited, we only conduct estimations up to the age of 19. As the results for the pooled sample of siblings differ from those for the full sample (see third column of Table 6), we regard them rather as sensitivity checks of the effects obtained in pooled regressions than as reliable alternative estimates. We do not attempt to interpret their magnitude at different ages but only examine their significance and overall magnitude.

We consider now three different specifications for the unobserved family effect: First we assume it is a fixed effect estimating a linear panel model. Then we introduce normally distributed random effects (RE) and correlated random effects (CRE) into a panel probit model. The correlated random effects are assumed to be linear functions of the mean skills of the siblings (see Chamberlain (1982)). For the nonlinear models we report average marginal effects with standard errors obtained from bootstrapping with 500 replications. When assuming a linear probability model, the fixed effects (FE) estimator is equivalent to the CRE estimator, so the FE estimates also provide a sensitivity check to the nonlinear CRE estimates (see Imbens and Wooldridge (2008)).

In the RE model the effect of both school grades and the Rotter index is always significant and except for 19-year-olds the magnitudes are not very far from the simple probit model. Yet it has to be noted that sample sizes are small and the overall explanatory power of the regressions is particularly weak in the last cohort (see Table 9). In the CRE model, the results on the effects of individual school grades and Rotter scores are similar to the results in the FE models, with the coefficients for school grades being somewhat lower (see Table 10). Mean school grades are significant for all cohorts, while the other variables are only significant for some.

The CRE estimation appears the most plausible specification since it assumes that family effects are not independent of mean observed skills and since it accounts 
Table 9: Estimation educational dropout with siblings sample, FE and RE

\begin{tabular}{lllllll}
\hline \hline & \multicolumn{2}{c}{$\mathbf{1 7}$ years } & \multicolumn{2}{c}{ 18 years } & \multicolumn{2}{c}{19 years } \\
& $\mathrm{FE}$ & $\mathrm{RE}$ & $\mathrm{FE}$ & $\mathrm{RE}$ & $\mathrm{FE}$ & $\mathrm{RE}$ \\
\hline Grade score & 0.003 & $-0.008^{* * *}$ & $-0.026^{* * *}$ & $-0.02^{* * *}$ & 0.003 & $-0.002^{* * *}$ \\
& $(0.005)$ & $(0.0017)$ & $(0.009)$ & $(0.005)$ & $(0.009)$ & $(0.0004)$ \\
Rotter index & $-0.008^{*}$ & $-0.006^{* * *}$ & 0.001 & $-0.003^{* *}$ & -0.006 & $-0.001^{* * *}$ \\
& $(0.0047)$ & $(0.001)$ & $(0.007)$ & $(0.001)$ & $(0.0065)$ & $(0.0004)$ \\
\hline Sample size & 329 & 329 & 247 & 247 & 204 & 204 \\
$R^{2} / C h i^{2}$ & 1.41 & $13.82^{* * *}$ & $4.17^{* *}$ & $11.90^{* * *}$ & 0.49 & 4.54 \\
\hline \hline
\end{tabular}

Notes: Average marginal effects. Standard errors are in parentheses: ${ }^{* * *}$ significant at $1 \%,{ }^{* *}$ at $5 \%$ and $* 10 \%$ level.

Source: SOEP 2000- 2007. Own calculation, sample 3.

Table 10: Estimation educational dropout with siblings sample, CRE

\begin{tabular}{llll}
\hline \hline & $\mathbf{1 7}$ years & $\mathbf{1 8}$ years & $\mathbf{1 9}$ years \\
\hline Grade score & 0.002 & $-0.016^{* * *}$ & 0.0006 \\
Rotter index & $(0.0017)$ & $(0.004)$ & $(0.001)$ \\
& $-0.008^{* * *}$ & -0.001 & $-0.002^{* *}$ \\
Mean grade score & $(0.0019)$ & $(0.0016)$ & $(0.0008)$ \\
& $-0.018^{* * *}$ & $-0.007^{*}$ & $-0.0065^{* *}$ \\
Mean Rotter index & $(0.005)$ & $(0.0038)$ & $(0.0028)$ \\
& 0.0017 & -0.004 & $0.0026^{*}$ \\
\hline Sample size & $(0.001)$ & $(0.002)$ & $(0.001)$ \\
$C^{2}$ & 329 & 247 & 204 \\
\hline \hline
\end{tabular}

Notes: Average marginal effects. Standard errors are in parentheses: ${ }^{* * *}$ significant at $1 \%,{ }^{* *}$ at $5 \%$ and $* 10 \%$ level.

Source: SOEP 2000- 2007. Own calculation, sample 3

for nonlinearity. It finds significant evidence of an average marginal effect of the Rotter index between 0.2 and 0.8 percentage points for two cohorts. This implies that a standard deviation difference in noncognitive skills (3.1 points) is related to a dropout probability that is 0.6 to 2.5 percentage points lower. The effect is not significant for 18-year-olds, where a significant effect of school grades dominates the results. Because of collinearity and the small sample size, the estimation may be unable to fully disentangle the effect of academic and noncognitive skills. Overall the results are in favour of the hypothesis that noncognitive skills reduce the risk of educational dropout even after controlling for family background and academic skills. 


\section{Conclusion}

We have investigated the determinants of being an educational dropout in the years during which young people at the lower end of the educational distribution should typically make the transition from school to vocational training and eventually to the labour market. The first main result of this paper is that noncognitive skills reduce the risk of being an educational dropout after controlling for school achievements and family background. With the instruments available in these data the effect remains robust after dealing with the possible endogeneity of noncognitive skills and school grades in IV models. The effect of the Rotter index also remains significant in most specifications estimated with a panel of siblings. This supports the hypothesis that the Rotter index reflects individual skills and not unobserved family characteristics. The second main result is that the effect is increasing with age. A possible reason is that successful integration and completion of the system of vocational training between the age of 19 and 21 depends more on noncognitive skills than completing school and entering this system immediately after school.

The IV estimation finds evidence of the endogeneity of school grades while there is no empirical support for the endogeneity of noncognitive skills in the present data. The result may to some extent be based on the fact that our data are not able to detect the main drivers of formation of noncognitive skills.

Across specifications, magnitudes of the negative effect of an increase in noncognitive skills by one standard deviation on dropout probability concentrate in the range between 1 and 4 percentage points. An increase in school grades by one standard deviation is related to a reduction in dropout probability between 3 and 8 percentage points in models that do not account for the endogeneity of grades. An instrumental variable estimation finds a higher average effect of 9 percentage points. Our results show that in addition to academic skills noncognitive skills play a role in the successful transition from school to the system of vocational training in Germany. The effect appears to be the more important, the older the individuals are. With further data becoming available it should be possible to extend this analysis to larger samples and older cohorts as well as to a more direct investigation of the interplay between the formation of cognitive, academic and noncognitive skills. 


\section{References}

Bayerisches Staatsministerium für Unterricht und Kultus (2008). Volksschulordnung - VSO.

Blomeyer, D., Coneus, K., Laucht, M. and Pfeiffer, F. (2009). Initial Risk Matrix, Home Resources, Ability Development and Children's Achievement, Journal of the European Economic Association, Papers and Proceedings 7(2-3): 1-11.

Borghans, L., Duckworth, A. L., Heckman, J. and ter Weel, B. (2008). The Economics and Psychology of Personality, Journal of Human Resources 43(4): 9721059 .

Carneiro, P., Crawford, C. and Goodman, A. (2007). The Impact of Early Cognitive and Non-Cognitive Skills on Later Outcomes, Working paper, Centre for Economics of Education .

Chamberlain, G. (1982). Multivariate Regression Models for Panel Data., Journal of Econometrics 18(1): 5-46.

Cunha, J. and Heckman, J. (2008). Formulation, Identifying and Estimating the Technology of Cognitive and Noncognitive Skill Formation, Journal of Human Resources 43(4): 738-782.

Dahl, R. E. (2004). Adolescent Brain Development: A Period of Vulnerabilities and Opportunities, in R. E. Dahl and L. P. Spear. eds., Annals of the New York Academy of Sciences, New York Academy of Sciences.

Duncan, G. J., Claessens, A., Huston, A. C., Pagani, L. S., Engel, M., Sexton, H., Dowsett, C. J., Magnuson, K., Klebanov, P., Feinstein, L., Brooks-Gunn, J. and Duckworth, K. (2007). School Readiness and Later Achievement, Developmental Psychology 43(6): 1428-1446.

Dustmann, C. (2004). Parental background, secondary school track choice, and wages, Oxford Economic Papers 56(2): 209-230.

Flossmann, A. L., Piatek, R. and Wichert, L. (2007). Going Beyond Returns to Education: The Role of Noncognitive Skills on Wages in Germany, University of Konstanz, Unpublished Paper.

Franz, W., Inkmann, J., Pohlmeier, W. and Zimmermann, V. (2000). Young and Out in Germany. On Youths' Chances of Labor Market Entrance in Germany., in D. Blanchflower and R. B. Freeman, eds., Youth Unemployment and Joblessness in Advanced Countries, Chicago Press.

Heckman, J. J. and Rubinstein, Y. (2001). The Importance of Noncognitive Skills. Lessons from the GED Testing Program, American Economic Review 91(2): 145149. 
Heckman, J. J., Stixrud, J. and Urzua, S. (2006). The Effects of Cognitive and Noncognitive Abilities on Labor Market Outcomes and Social Behavior, Journal of Labor Economics 24(3): 411-482.

Imbens, G. W. and Wooldridge, J. M. (2008). IRP Applied Microeconomics Workshop - Lecture Notes.

MaCurdy, T., Keaton, B. and Nagavarapu, S. S. (2006). Profiling the Plight of Disconnected Youth in America, Working Paper.

Ministerium für Schule und Weiterbildung des Landes Nordrhein-Westfalen (2008). Ausbildungs- und Prüfungsordnung Sekundarstufe I .

Murnane, R. J., Tyler, J. H. and Willett, J. B. (1998). Estimating the Impact of GED on the Earnings of Young Dropouts Using a Series of Natural Experiments, Working Paper No. 6391.

Murnane, R. J., Tyler, J. H. and Willett, J. B. (2000). Do the Cognitive Skills of School Dropouts Matter in the Labor Market?, Journal of Human Resources 35(4): 748-754.

Quintini, G., Martin, J. P. and Martin, S. (2007). The Changing Nature of the School-to-Work Transistion Process in OECD Countries, IZA Discussion Paper No. 2582.

Rotter, J. (1966). Generalized Expectancies for Internal versus External Control of Reinforcement, Psychological Monographs, 80 .

Ryan, P. (2001). The School-To-Work Transition: A Cross-National Perspective, Journal of Economic Literature 39(1): 34-92.

Senatsverwaltung für Bildung, Wissenschaft und Forschung des Landes Berlin (2005). Verordnung über die Schularten und Bildungsgänge der Sekundarstufe I .

Uhlendorff, A. (2004). Der Einfluss von Persönlichkeitseigenschaften und sozialen Ressourcen auf die Arbeitslosigkeitsdauer, Kölner Zeitschrift für Soziologie und Sozialpsychologie 56(2): 279-303.

Wagner, G. G., Frick, J. and Schupp, J. (2007). The German Socio-Economic Panel Study (SOEP)- Scope, Evolution and Enhancements, Schmollers Jahrbuch 127(1): 139-169. 